\title{
AN EVALUATION OF THE CANONICAL APPROACH: IS IT ADEQUATE FOR THE TASK OF OLD TESTAMENT THEOLOGY IN CHRISTIAN HERMENEUTIC ENDEAVOUR?
}

\author{
GC (Piff) Pereira \\ North West University
}

Biblical Studies

Baptist Theological College of SA

\begin{abstract}
:
The overarching question is: "How do we make the biblical text relevant for our present context?" The answer ultimately resides in reading the text theologically. Therefore, the question must be: "How do we read the Old Testament theologically?" This article shows that the canonical approach to Scripture brings out the theological significance of the text because it allows a number of windows to illuminate the exegetical task. In the article's consideration of literary form, it acknowledges that narrative is a sizeable window into both the historical and theological. Another window to Scriptural intentionality is found in the given shape of the Canon. The unity and, therefore, continuity of the text provide a large window to theological relevance. This article also intimates a smaller, but significant, window in aspects of biblical tradition, through programmatic themes. The Canon, however, with its varied literary forms, its tentative historical facts, and its veiled traditions, must stand out as the only constant in the theological task. Therefore the canonical approach to reading the text is indispensable to Old Testament exegesis and to Christian hermeneutics.
\end{abstract}

Key Words: Canon; Canonical Shape; Canonical Approach; Narrative; History; Historic-Critical; Critical Analysis; Exegesis; Christian; Tradition

\section{Introduction}

The meaning and the rationale of the topic title must be clarified before we continue our discussion. Its plain statement is that the main aim of the article is to evaluate whether the canonical approach is adequate for doing Old Testament theology and Christian hermeneutics. Old Testament theology is to be distinguished from Christian hermeneutics, even though the latter depends on the former; firstly, because the Old Testament is not a Christian document and secondly, because Christians have adopted it as part of their Scriptures from the earliest times of the New Testament. In the New Testament they demonstrate ways in which the Old Testament is employed as Christian Scriptures. So therefore, I must first bolster my preference for the canonical approach as a method of exegesis, and then demonstrate how it allows its 'inadequacies' to be compensated for in the task of theology. Then I must show that Old Testament theology has implications for Christian hermeneutics. 
The first decision for a theoretical framework is whether one uses a diachronic or a synchronic approach to the text. The former looks at the development of the text over time, while the latter looks at the text as it exists at one point in time. That is the essential difference between the Historical-Critical approach and the Canonical approach. Each has its advantages and its disadvantages. Nevertheless, our quest is for the best theological reading of the Old Testament, and that is immensely stifled by the diachronic approach's natural text-atomising tendency.

In an earlier paper ${ }^{1}$ of mine, I demonstrated that biblical scholarship is becoming more and more disenchanted with Historical-Criticism as a method due to its text-atomising character. German scholar Eckart Otto admits that a purely diachronic methodology at times loses the given text in its analysis (2007:24). Even though Vervenne (1994:80-98) states that synchronic biblical analysis is not very common among German scholars, there are some who admit to its advantages. Another German scholar, Martin Noth, for instance, agrees with the idea that theology is best explicated from the 'final form' of the text (1959:18). An admitted pro-historical-critical Old Testament scholar, Jurie le Roux, addresses this and the pastoral concerns when he advises: "Een so 'n moontlikheid (vir die studie van die Pentateug) is om voorlopig literêre-kritiese analise te vermy en eerder op die groot vorm (Enneateug) en teksblokke (soos die aartsvaders en die uittog) te fokus. In dié proses kan die pastorale waarde van die Pentateugkritiek ook beklemtoon word"2 (2005:27). With this statement he shows a preference for a synchronic reading in order to emphasise any pastoral value.

The critical method is unable to provide relevance and is inadequate for the theological tasks. It is unable to span the distance between the 'then' and the 'now' because it tends to imprison the text in the past (Klingbeil 2003:403). As indicated above, it is also inadequate for life's practicability and the pastoral task. Marion Carson (2010:340) cites Stephen Pattison: "This minute, historical, critical and analytical perspective has yielded many benefits, but it has also had the effect of making it very difficult to integrate specific textual insights with broad theological concerns, or with Christian life in general". Its problem is that it regards only empirical reality at the expense of transcendent reality, because, as Ebeling states, "it has no room for transcendence" (1963:79-97). Nevertheless, historical observation can neither demonstrably prove nor disprove the operative providence in history (Henry 1999:2:316).

Many of those disenchanted with the Historical-Critical method have found in Brevard Childs' canonical approach the answers to their need for history and theology to work in tandem for the benefit of the faith community. The revelatory and historical aspects of Scripture require both a theological and historical method of investigation, because faith and fact are not mutually exclusive terms. It recognises that any investigation into Scripture must treat both as necessary (Pereira 2013:2). The canonical approach understands that canonisation is chiefly an expression of faith in its whole process (Childs 1970:104), which starts with revelation, through inspiration, enscripturation, recognition, collection, canoni-

"The Need for a Canonical Reading of the Exodus Narratives in Finding its Present-day Theological Significance" in Verbum et Ecclesia, 2013.

2 A fairly literal translation in English reads: "One such a possibility (for the study of the Pentateuch) is to provisionally avoid literary-critical analysis and to rather focus on the larger form (Enneateuch) and texts (such as the patriarchs and the exodus). In this process the pastoral value of Pentateuch-criticism may also be emphasised." 
sation, and the whole process is circumscribed by divine providence. 'Revelation' reflects the concern to be open to the theological dimensions of the biblical canon (Pereira 2010b:5)

Yet, it must be admitted that the Historical-Critical method is not without significance in the task of exegesis, and that the Canonical approach is not without inadequacies of its own. The Canonical approach is still subject to the possibility of a too narrow application. It is therefore necessary for the biblical student to take up the challenge to employ the broadest applications possible that will produce the most comprehensive and most accurate exegetical results. He must find the necessary historiographic confidence and accuracy on the one hand, and the meaningful inner-relationship of the text on the other. He must also realise that theological reflection is necessary for deriving contemporary relevance; thus allowing for a Christian interpretation of the Old Testament. A Christian interpretation will reinforce the necessary continuity between the Testaments, and also between Israel and the Church (Pereira 2013:11).

Historical-Critical findings have obscured the intentionality heard by the New Testament, and have prevented the Old Testament from speaking as Christian Scripture (Seitz 2004:157). After all, the Old Testament was used by our Lord Jesus and the Apostles without tension. Fleming $(2005: 21)$ comments that the Apostles moved from an Old Testament monotheistic-creationist-redemption paradigm to preach Jesus within their context. I will therefore critically evaluate the Canonical approach with the aim of suggesting ways to improve its exegetical and kerygmatic results, taking my prompt from Gorman's (2009:12) attitude when he says that exegesis is both a science and an art, not forgetting its supernatural character as well; and from Goldingay's (2001:113) observation:

The assured results of modern criticism have all ceased to be assured... The Old Testament scholarly world corporately does not know anything about when those books [the Pentateuch] were written or what their historical value might be. Perhaps it has moved from the pre-modern position (Moses wrote the Pentateuch) through the modern position (JEDP wrote the Pentateuch) to the post-modern position (we do not know who wrote the Pentateuch, and it was probably the wrong question).

The exegete's basic enquiry must first observe the inner character of the biblical text, and how it was meant to address the faith community before it can look at the detail of the text. The ideas of literary form, canonical shape, historical necessity and Christian tradition will be considered here.

\section{Narrative in the Biblical Text}

From a Literary Form perspective, the inner character of the biblical text is essentially narrative. The Bible is in fact a collection of written documents with a variety of literary forms by a multiplicity of authors in a variety of contexts at different times. It is framed within Israel's and the Church's historical narratives. The dominance of the narrative form is utilised to tell stories, all part of a big story about God and the people of God (in the first testament, Israel, and in the second testament, the Church). That narrative is also the substrate for other forms in the text such as divine speech, Law, the Didactic, Wisdom, Poetry, etc. Biblical narrative is written with theological purpose. The other forms are given meaningful theological shape within that narrative substrate.

Goldingay (2008:5) demonstrates that narrative makes possible the discussion of theological questions. In fact, narrative makes possible a number of responses. Douglas $\mathrm{S}$ Earl (2011:38-39) states that narrative is able to guide the reader subtly and carefully towards deliberate perspectives and themes. Even underlying narrative structure and 
symbols take the reader in new directions, encouraging the desired changes and responses. The stories told in the Old Testament narrative include events that actually happened in the life of Israel. These stories in the Old Testament chiefly tell about the acts and pronouncements of God, mainly in relation to Israel, and sometimes in relation to the surrounding nations. Israel's identity is defined chiefly by the historical narrative of the Old Testament. Narrative, thus, is that by which history is recorded; by which moral promptings are given; by which other literary forms are encased; and by which theological truths are proffered. So, narrative can do more than record history. Narrative is such that it is often not easy to distinguish between history and non-history. This is where historical analysis is necessary. The place in exegesis for historical analysis must always be open.

\section{Canon and Narrative}

In our discussion on canonical shape, we must first broadly define Canon. The Canon of the Old Testament is the body of divinely inspired Scriptures, which are accepted by the community of faith (Jewish and Christian) as authoritative for belief and practice. House (1998:57) defines it as the Old Testament message which is God-centred, inter-textually oriented, authority-conscious, historically sensitive and devoted to the pursuit of the wholeness of its content. It is the norm and the resource for the spiritual formation and common identity of the people of God. More definitions can be heaped up, with a nagging consciousness that much more reflection is needed on this topic. Kruger believes that a single definition fails to capture the depth and the breadth of canon and may end up bringing more distortion than clarification (2012:1-2). His concern is not the word 'Canon' itself, but the concept to be derived from socio-historical and theological phenomena.

Those who hold the exclusive definition of 'Canon' believe that it is a body which has a fixed list of books to which nothing can be added or from which nothing can be taken away. J Barton, for instance, preferring the exclusive definition, says: "Much clarity could be gained if we agreed to distinguish sharply between two concepts [of scripture and canon]" (2003:202). The implication of this statement is that there are those who hold to the idea that the canon is open. Their argument is that as there was no canon in the fourth century, we cannot speak of a canon even today (Kruger 2012:6). Some posit various canons, and in that way ascribe relative authority or no authority.

The whole discussion on Canon is greatly reduced with the Old Testament. This is so because it is the Jewish Scriptures; the Scriptures that Jesus and the Apostles used. By the time of Christ the Jewish Scriptures were 'stabilised'. ${ }^{3}$ It can be established with a fair amount of certainty that the Old Testament canon was what Christians have inherited from first century Judaism. The order of books may differ slightly, but that is not serious in my opinion. Seitz (2008:28), responding to Goldingay, reminds us that the actual fact is that the only order that settles down in the history of the Old Testament's reception is the tripartite of the Hebrew order (with some movements in the Writings). We need to take Seitz's concern seriously; that recourse to narrative must not unduly loosen theological points made by the present arrangements (2008:30).

Nevertheless, Childs contradicts the exclusive definition. saying that the term 'Canon' encompasses the whole process by which the formation of the church's sacred writings took place (1984:25). Because he argues against a distinction between Scripture and Canon,

This concept is used by Childs (1979:93), 'When the Hebrew text of the Jewish community reached the point of stabilization in the first century AD, and the term "canonical text" could be applied to it'. 
he believes that the term 'Canon' can be employed as soon as a book was regarded as 'Scripture' by early faith communities. This is the functional definition of canon. Goldingay (2008:2-4) cites Childs as saying that the individual books of the Old Testament have been shaped to function as Canon. The providential process towards a comprehensive Canon is always in view.

There is also the ontological definition, which is retrospective in nature. Kruger says, "It focuses on what the canon is in and of itself, namely the authoritative books that God gave his corporate church". He continues, "It says that books do not become canonical they are canonical because they are the books God has given as a permanent guide for his church" (2012:14). We can see that the Canon is 'a theological issue' (Filson 1957:42). The Canon is therefore our authoritative Scriptures. Contra William Abraham (1998:51), I believe that the Canon is both a rule and criterion for truth and a means of grace for salvation.

The canonical shape (form) of the Old Testament is to be studied in its own right as Scripture. It has its own voice that comes from its ordering and form to provide its own theology for the benefit of the community of faith. The Old Testament has to be allowed to function as canon because this is the only established form from which we may move forward. We need to hear Israel's testimony (Seitz 2008:32).

Yet, the study of the Old Testament presupposes that there is a New Testament. It predates the New Testament, and is therefore to be read for its own message. We are not to reinterpret immediately the Old Testament theologically in the light of the New Testament. We must only allow the New Testament to agree with the Old Testament where it does so naturally, or where it says something completely new. Yet, because we can notice a connection between the two Testaments, we may also accept that there must be a reciprocal illumination between them. Canonical interpretation must allow each Testament to have its own distinctive 'voice'. We would do well to heed Brueggemann's conviction: "Old Testament theological articulation does not conform to established church faith" (1997:107). Seitz (2008:31) shares the same sentiment when he says, "...what the church believes it believes reliably, because it has a living testimony going back to the apostles."

There seem to be two views about the idea of a 'canon within the canon'. In the one sense certain portions are excluded from the divine Scriptures, while the rest of the Canon is said to be human Scripture. To this attitude Meier (1977:50) warns that Scripture does not permit itself to be separated into a 'divine Scripture' and 'human Scripture'. Linemann (1990:85-88) also expresses a contrary attitude when she says that critical reason should not decide what is reality in the Bible and what cannot be reality. The other sense of 'canon within the canon' does not exclude the 'outer canon' as Canon; it simply allows a suspicious hermeneutic to be applied to certain texts that may be categorised as allowances made for human stubbornness (Goldingay 2008:16-17). It is still part of Scripture. The term 'canon within the canon' must then be stated with qualification; the one way of thinking excludes some scripture as authoritative, and the other way of thinking distinguishes between the 'absolute' will and the 'foreign' will of God; but nevertheless the will of God and authoritative.

We should do Old Testament theology on the basis of the books' canonical form rather than on a basis of Critical hypotheses about their origins [as historical-criticism postulates]. Goldingay (2008) continues by admitting that it can be enlightening to consider the theological implications of the ordering of the books in the Canon (p. 3). He goes further by 
positing that the Canon, being dominated by narrative, signifies for Old Testament theology that Israel's faith is a gospel, a story declaring good news about what God has done (p. 4).

I had to defend my canonical stance to my supervising professor when I was doing my second doctorate. Here is an excerpt from a letter addressed to Professor Le Roux:

We strongly disagree with the notion that a canon has not been finalised. We can talk about a final text for the communities of faith. The final text is the majority text, accepted generally in both Judaism and Christianity. The history of the Church adequately demonstrates that the matter was debated and laboured until a majority consensus was reached. Ante-Nicene fathers like the outstanding translator, exegete and theologian, Jerome in the fourth century played an influential role in settling the issue of canon. The canon for Judaism was also pretty much settled by the time of Christ. The canon was never settled by a sanction, but only by listing the writings that were already acknowledged. From where we stand, we can certainly speak about a final text, acknowledged early in the church's history, even if it is by the universally accepted connotations of 'canonical' and 'deutero-canonical'. In fact, we even accept that the process was providential; we have a finalized text by God's providence. (Pereira 2008:1-2).

As we have said, the Canon is dominated by narrative in framework and in substrate, and includes other forms. Goldingay (2008:5) demonstrates that that fact makes possible the discussion of theological questions. Old Testament narrative has theological implications because it is written with a theological purpose. Narrative makes it possible, for instance, to discuss the relationship between divine identity and requirements; divine sovereignty and human free will; divine presence and relationships; divine promise and fulfilment; etc. The canonical shape of [the] given text has a theological purpose and has a theological effect (Jolley 1987:36). According to Snyman (2002:179-181) the theological effect allows the narrative to be used for moral meaning gleaned from timeless principles which are not enforced by an epistemological framework. Such timelessness, he continues to say, is possible because human societies always have features that resemble those of others and because "narrative is part of being human" (p. 197). Although narrative enables us to do all these things, we cannot overlook the importance of canonical order. This will be discussed further below.

\section{Canonical Shape and Order}

In his discussion on the Twelve, Seitz (2004:159-160) reminds us that three questions were crucial in encouraging scholarly interest in 'the larger book'. Obviously, he was referring to the Twelve, but the principle clearly also applies canonically in its broader context. Firstly, why does it circulate as one book? Secondly, how does one honour individual prophetic books, but also a given organisation and sequence? ${ }^{4}$ And thirdly, how may the final form editing of one match move into the other?

The first question highlights the tension that must be faced in questions of authenticity with reference to the seriousness about theological matter on the one hand, and of literarycritical issues on the other. There is, for instance, the case of one prophet using language from another - e.g. “... the Lord roars from Zion and thunders from Jerusalem” (Joel 3:16

4 The rabbis counted the words of the whole collection, and the earliest reference in Sirach speaks of the Twelve as a whole, and not as isolated men in a more accurate chronological order (Seitz 2004:160). 
cf. Amos 1:2). We must notice such literary peculiarities, which are often also points of theological connectedness.

The second question forces us to think about the canonical shape and order, which posit a meaningful inner relationship within the text. The matter of order is accepted for what it is, thus seeing different relationships; with what goes before, and with what comes after. It regards the collective witness of the final form presentation as bound to the individual witness. The converse is also true.

The third question is closely linked to the second; namely, that matters of interdependence and association are important. There is a larger organisational coherence in the canonical shape. The editorial and compositional factors must be understood as important hermeneutical signals for the theological task. Nogalski (2007:115) agrees with Seitz when he observes: "While some scholars express caution about how much can be said regarding editorial cohesion, most working in this field have postulated that, to some degree, this tradition of unity reflects the theological and literary agendas of the editors of the Twelve, not merely a convenient repository for twelve prophetic writings". Seitz speaks of an intentional speech-act in the literary given-ness, and the ability of the Bible to relate as its own system of cross-reference intratextually (2004:157). I believe that it is in order for me to appropriate Seitz's comment for my broader canonical agenda (and against a diachronic agenda) at this point:

My more contentious point is that those who claim that their reading is more historically appropriate - a reading in which the individual prophets are isolated from one another, recast according to date, and placed in a reconstructed temporal context - are actually the ones who are not reading the prophets sufficiently historically. For final canonical form is also a piece of history, belonging to decisions made in the past about how an ancient prophetic witness is finally to be heard (2004:161).

The point is that the individual prophet (author) belongs to a larger and inter-related history of other prophetic voices and of the people of God.

Finally, if the canonical order may have theological influence, then one must pay careful attention to the Hebrew order of the Old Testament. Seitz (2008:30) is justifiably worried that recourse to narrative could unduly loosen theological points made by the present arrangement. Narrative must therefore be the narrative derived from the canonical order, rather than the other way around. The Canon must occupy the primary position over theology and narrative.

\section{History and Narrative}

We now consider the issue of historical necessity. Israel's faith is founded upon its selfunderstanding and an identity derived from its history. Most influential is the Exodus story in this history. This fact is demonstrated by the repeated reference to their redemption story throughout the Old Testament - and in the New Testament (e.g. 1 Kg. 8:51; Neh. 9:9-12; Ps. 78:11-16; Is. 51:10; Mi. 6:4; Hab. 3:8-10; Hg. 2:4-7 and Acts 7:17-37). Their faith comes from a theological reflection based on the narrative in the Old Testament text and not the events or experiences behind the text. The story told in that narrative must also refer to things that have actually happened with ongoing theological significance. The story is a telling of what God has done for them. God made promises to them (e.g. Dt. 4:31); he delivered them (e.g. $1 \mathrm{Kg}$. 8:51); he sustained them in the wilderness (e.g. Jos. 24:7-8); he covenanted with them (e.g. Ex. 24); and so the story is recorded in Scripture. Goldingay agrees that "An Old Testament narrative theology is dependent on the factuality of the 
events it refers to" (2008:7). He concludes that the basic historicity of the events related in the Old Testament is important to the validity of its theology, and this is one reason why the study of Israelite history deserves investigation (p. 7).

Unfortunately Old Testament study is never going to establish what events lay behind the canonical Old Testament narrative. For the two centuries spent by critical scholarship on their quest for the historical Israel, little progress has been made and little possibility of real 'break-through'. Goldingay (2001:114) observes the emergence of a sobering fact from the story of biblical criticism over the past two or three decades ${ }^{5}-$ in that critical study will never come to definitive conclusions about Old Testament history. This is so because they were looking for historical facts in a text that was not written to be a history book. They did not give due consideration to the matter of historiography and the distinction and tension between Historie and Geschichte. Pereira (2013:7-8), also citing Childs, states that from a canonical context the question of Geschichte or Historie is settled, because the canonical approach views history from the perspective of Israel's faith-construal. Kerygmatic history and Salvation History (Heilsgeschichte) place themselves in the Geschichte camp. Although different dimensions of history are recognised freely, by focusing on Israel's historical role as the bearer of the traditions of faith, these two aspects of history (Geschichte and Historie) are held together in a subtle balance within the shape of the Canon, and should not be threatened by some overarching theory of history (Childs 1985:16). Brueggemann (2012:33) prefers to put historicity in abeyance, reminding us of GE Lessing's famous 'ugly ditch' in which the crossing from 'history' to 'meaning' is difficult and even impossible. The endless sorting out of Historie and Geschichte adds little to the theological endeavour. Even though Brueggemann is hesitant to speak about canonical shape as does Childs, he does speak about biblical testimony as a speech-event with theological relevance (2014:36).

Israel's history is framed in narrative. The narrative framework clearly indicates a story of their calling (through Abraham), redemption (from Egypt), favour (with Presence), relationship (by Covenant), possession (of the Promised Land), monarchy (rather than theocracy), captivity (in Babylon) and restoration (to the Land). The Law and prophetic proclamations/injunctions are present within this narrative substrate, and reciprocatingly influences and regulates the ongoing story of the Israelites. There is sufficient historical value in the Old Testament to justify the theology that is built on them. Even though he sees the careful pontifical formulation as partly theoretical, Eugene Ulrich concedes that the statement, "It is the canonical text in its final stage which is the expression of the word of God" requires empirical analysis (2004:17). His call for empirical analysis in this context can be interpreted as meaning that historical analysis must also have theological concern.

Goldingay (2008:9) is convinced that Old Testament theology allows the Canon itself to be the Canon. Old Testament theology does not require only a narrative form, or only historical data. In fact narrative is not always easily recognised as historical. Old Testament theology recognises that not everything in the Old Testament needs to be historical fact. The canon has the freedom to have parables, poetry and fiction from which theology and theological ethics may be derived. The Canon is the constant factor and the historical facts still to be discovered have to be tentative. While this is so, we urge that historical enquiry should not be stifled, nor stifling. We now consider the issue of Christian tradition as part of the canonical approach to exegesis and theology.

Now, more than four decades. 


\section{Tradition and the Canonical Approach}

We could have discussed the aspect of tradition under the heading of history, but I wish to define it here as history that may include history outside the canon. When we refer to tradition we are concerned with ecclesiastical and theological traditions. While Childs ${ }^{6}$ does interact with the history of theological interpretation in his canonical approach, he always sees it as an addendum to actual Old Testament theology. Ecclesiastical tradition and doctrine also have to be treated as tentative. Yet, it is not without significance in the task of Old Testament theology. Let us demonstrate this by Evangelical tradition as a case in point.

Goldingay (2001:99) is convinced that Evangelicals should do Old Testament study within the framework of the Gospel. The New Testament authors did so. Paul, for instance, spoke about a relationship with God made possible by salvation through categories of Righteousness (the OT holiness-motif), Redemption (the Exodus-motif) and Reconciliation (the Atonement-motif). These Old Testament categories are all bound within the programmatic Heilsgeschichte theme. Other programmatic themes in the Old Testament extending into the New Testament - include, but are not exhausted by, 'Presence' and 'God's People'. A brief demonstration of these two themes will suffice to make my point. Firstly, in the Old Testament God's presence is displayed in instances of divine speech, theophanies, symbols and powerful acts. In the New Testament God's personal presence came to be with humans when God became a man in the person of the Son. When the Son ascended to heaven, the Spirit of God came to indwell and empower all believers. Adrio König summarizes the unfolding 'Presence programme' as "God for us; God with us; God in us" (1989:11). Secondly, both the Old Testament and the New speak about a relationship with God in the core covenant statement, "....and I will be their God, and they will be my people." ${ }^{, 7}$ Here, many Evangelicals speak about continuity between Israel and the Church.

Gordon Fee (1993:422) asserts that all hermeneutics is done within a circle, or circles, of tradition. He demonstrates that 'tradition' through Church history was often given equal status and authority with Scripture, an understanding which those within the Evangelical tradition reject, but who nonetheless frequently interpret Scripture through the lenses of their own personal and theological traditions. Evangelicalism is divided into Evangelical, Pentecostal, Charismatic traditions, and the like. Beyond that, one's personal history (experiences, sociology, culture, family, ecclesiastical and national histories) also bears on one's own hermeneutics. We are predisposed toward a given theological system. We accept that a presupposition-free exegesis is not possible. We are therefore culpable of being selective in our hermeneutics.

Fee goes on to state that problems emerge when these traditions are not recognised as such and therefore often intrude upon or impede the exegetical and hermeneutic enterprise (1993:423). He continues to say that the positive thing is that the ability to hear the texts through the ears of other traditions may serve as one of the best exegetical or hermeneutical correctives we can bring to the task (p. 432). We do not, for instance, have to look at the text with the presuppositions of 19th Century Idealism. Evangelicals will admit that the personal history alluded to by Fee (1993:433), is not to be considered as canonical, nor as authoritative.

Theology resides in the text. The biblical text of one Canon must hold the place of priority (Green 2002:10). John Goldingay (2001:100) correctly states that the structure of

Childs, Brevard. 1985 Old Testament Theology in a Canonical Context. London: SCM Press.

This statement in its varied kindred forms is first promised to Abraham in Gen.17:8, and occurs throughout the Bible until its culminating mention in Rev. 21:3. 
Old Testament faith is itself the structure of the Gospel - or rather, the structure of the Gospel is the structure of Old Testament faith. This is supported by the recognition of programmatic themes in the Old Testament. The Gospel story is a continuation of the Old Testament story. Evangelical study assumes that God gave the Bible in its entirety. Therefore they consider the whole Canon with absolute seriousness. The canonical approach is a basic Evangelical approach to the study of the Old Testament, and indeed, for the whole Bible. Therefore this Evangelical tradition is actually regarded as biblical (and thus canonical). I think that Qumran Scrolls expert, Eugene Ulrich's statement on Scripture and tradition is an apt one at this point: "Helpful to the discussion of Scripture and tradition is the perception that Scripture is tradition" (2004:20).

While every book in the Canon is considered as the inspired Word of God, we know that not every detail is historical fact. Historical fact matters to Evangelical study and every effort must be made to establish historical facts, but faith allows them to understand that not all textual narrative needs to be historical, and to accept that the Canon has sufficient fact for theological investigation.

So, we see that the Canon and history are important. But we also see that factual history is not going to hamstring Evangelical exegetical endeavour. Some will be more insistent on historical fact on all matters than others. Each one will approach the text with his particular emphasis - as for example according to Goldingay (2001:112), Childs is concerned with right thinking and belief, and Brueggemann with right behaviour and social relevance. Holmes (2009:53) having compared Evangelical attitudes about the Bible on both sides of the Atlantic, comes to the conclusion that: "North American Evangelicalism, with a broad commitment to inerrancy, views the Bible primarily as a collection of facts to be believed; [while] British Evangelicalism, stressing instead authority, views the Bible primarily as a collection of rules to be obeyed."

Fee's comment is important here: "Exegesis and hermeneutics, even when worked on or worked out in the privacy of one's own study, must finally be the product of the Christian community at large. At this point it must be said that we all stand indebted to that long history of orthodox consensus" (1993:433).

\section{Conclusion}

We have shown the importance of reading the Old Testament theologically. In order to maintain a historiographic confidence and accuracy on the one hand and a meaningful inner-relationship of the text on the other, Scripture must be approached canonically. We see that narrative plays an important part in providing both historical and theological insight, and allows itself to be a substrate for other literary forms in the text. The realised aim of the canonical approach is the endeavour to keep the Scripture intact as a unified and continuous text. The shape of the Canon holds together in balance the two aspects of history (Geschichte and Historie), allowing no real impediment to the theological endeavour. History and theology must work together because fact and faith are not mutually exclusive terms. We have seen that we must maintain the Canon's shape and order. The very shape has historical significance and brings out the theological intentionality, which the biblical student must hear. The canonical shape provides the Bible its ability to relate its own intra-textual system of cross-referencing. It is in this shape that programmatic themes are revealed in order to establish what we might call 'canonical traditions'. Here, we admit that the canonical approach needs to hear Christian tradition too. The canonical approach recognises that historical analysis need neither be stifled nor 
stifling in the exegetical task. The canonical approach of Old Testament study, not only keeps history and theology together, but also provides relevance for today. The Old Testament and its theology can thus be interpreted as Christian Scripture and made relevant to the Church.

\section{BIBLIOGRAPHY}

Abraham, William 1998. Canon and Criterion in Christian Theology. Oxford: OUP. Barton, J 2003. "Canonical Approaches Ancient and Modern" in The Biblical Canons. Leuven: Leuven University Press.

Brueggemann, W 1997. Theology of the Old Testament. Minneapolis: Fortress Press. Carson, Marion 2012. "Deep Heat and Bandages? Historical criticism, bounded indeterminacy, and pastoral care" in Evangelical Quarterly 82:4:340-352.

Childs, Brevard 1970. Biblical Theology in Crisis. Philadelphia: Westminster Press.

Childs, Brevard 1984. The New Testament as Canon: An Introduction. London: SCM Press.

Childs, Brevard 1985. Old Testament Theology in a Canonical Context. London: SCM Press.

Earl, Douglas S 2011. “Towards a Christian Hermeneutic of Old Testament Narrative: Why Genesis 34 Fails to Find Christian Significance" in The Catholic Biblical Quarterly 73:1:30-49.

Ebeling, G 1963. Word and Faith. London: SCM Press.

Fee, Gordon D 1993. "Exegesis and the Role of Tradition in Evangelical Hermeneutics" in Evangelical Review of Theology 17:4:421-436.

Filson, Floyd 1957. Which Books Belong in the Bible? A Study of the Canon. Philadelphia: Westminster Press.

Fleming, Dean 2005. Contextualization in the New Testament. Leicester: Apollos.

Goldingay, John 2001. "What Are the Characteristics of Evangelical Study of the Old Testament?" in The Evangelical Quarterly 73:2:99-117.

Goldingay, John 2008. "Old Testament Theology and the Canon" in Tyndale Bulletin 59:1:1-26.

Gorman, Michael 2009. Elements of Biblical Exegesis. Peabody: Hendrickson Publishers.

Green, Joel B 2002. "Scripture and Theology - Failed Experiments, Fresh Perspectives" in Interpretation 56:1:5-20.

Henry, CFH 1999. God, Revelation, and Authority. Wheaton: Crossway Books.

Holmes, Stephen 2009. "Evangelical Doctrines of Scripture in Transatlantic Perspective" in The Evangelical Quarterly 81:1:38-63.

House, Paul 1998. Old Testament Theology. Downers Grove: IVP.

Jolley, MA 1987. The Canonical Approach of Brevard Childs. Michigan:

Southern Baptist Theological Seminary.

Klingbeil, GA 2003. "Historical Criticism" in Dictionary of the Old Testament Pentateuch. Alexander and Baker (eds.). Leicester: IVP.

König, Adrio 1989. The Eclipse of Christ in Eschatology. Grand Rapids: WB Eerdmans. 
Kruger, Michael 2013. "The Definition of the Term 'Canon"” in Tyndale Bulletin 63:1:1-20.

Le Roux, JH 2005. "Die Pentateug tussen deel en geheel" in Old Testament Essays, Vol.18/2:265-280.

Linnemann, Eta 1990. Historical Criticism of the Bible: Methodology or Ideology? Grand Rapids: Baker Books.

Meier, Gerhard 1997. The End of the Historical Critical Method. USA: Concordia Publ. House.

Nogalski, James D 2007. "Reading the Book of the Twelve Theologically" in Interpretation 61:1:115-122.

Noth, Martin 1959. Exodus. London: SCM Press.

Otto, Eckart 2007. "A Hidden Truth behind the Text or the Truth of the Text: At a Turning Point in Biblical Scholarship Two Hundred Years after De Wette's Dissertation Critico-Exegetica" in South African Perspectives on the Pentateuch-Between Diachrony and Synchrony. Le Roux, JH and Otto, E (eds.). London: T\&T Clark.

Pereira, GC 2013. "The Need for a Canonical Reading of the Exodus Narratives in Finding its Present-day Theological Significance" in Verbum et Ecclesia. Pretoria: University of Pretoria.

Pereira, GC 2013 (2010). A Letter to Professor Jurie le Roux dated 22 September 2010. Unpublished.

Pereira, GC 2013 (2010b) "The Application of the Exodus Divine Presence Narratives as a Biblical Socio-ethical Paradigm for the Contemporary Redeemed.” Pretoria: Unpublished Doctoral Thesis - Pretoria University.

Seitz, Christopher 2008. "Canon, Narrative, and the Old Testament's Literal Sense” in Tyndale Bulletin 59:1:27-34.

Seitz, Christopher 2004. “On Letting a Text 'Act Like a Man'- The Book of the Twelve: New Horizons for Canonical Reading, with Hermeneutical Reflections” in Scottish Bulletin of Evangelical Theology 22:2:151-172.

Snyman, Gerrie 2002. "Narrative rationality, morality and readers' identification" in Old Testament Essays 15/1:179-199.

Ulrich, Eugene 2004. "Our Sharper Focus on the Bible and Theology Thanks to the Dead Sea Scrolls" in The Catholic Biblical Quarterly 66:1:1-24.

Vervenne, Marc 1994. “The Sea Narrative Revisited” in Biblica Vol.75/1:80-98. 